\title{
A REVIEW ON IMPACT OF CLIMATE CHANGE ON FOOD INSECURITY ON AGRICULTURE
}

\author{
Velamuri Anila Swetha \\ Department of Genetics and Plant Breeding, Lovely Professional University, Punjab, India \\ DOI: https://doi.org/10.51193/IJAER.2021.7311
}

\begin{abstract}
Food Insecurity is one of the major problems in the present situation and also it is continuing from the past several generations. Impact of change in climate is the main cause for this condition. Insecurity is due to several factors such as drought, Heavy Rainfall etc. Global warming increases the temperature, mainly during night hours. It is harmful/damaging to grain filling stage which eventually leads to loss in weight of the grain of many crops. Climate change is the continual adaptation of temperature and exemplary weather patterns in a place, and also it may cause weather patterns to be less certain. Change in the climate with raised/hoisted atmospheric Carbon-di-oxide concentration and temperature sometimes known for impact of plant photosynthesis.
\end{abstract}

Keywords: Agriculture, Food Insecurity, Climate change

\section{INTRODUCTION}

Agriculture sector in India is vulnerable to climate change. Green house gases are a major source of Climate change which contribute to the greenhouse effect (Sutherst, R.W,1996). However, the changes in climate have far reaching the impact on agricultural production, which are feasible to challenge food security in the forthcoming (IPCC Chapter 5, 2010). Change in the Climate may have harmful effects on irrigated crop yields over agro-ecological regions both because of the rise in temperature and change in water availability (Gurdeep Singh Malhi et. Al, 2020). Climate change is a transformation in analytical properties of the climate system that exists over a period of time or indefinitely- conventionally at least 30 years, it is the continual adaptation of temperature and exemplary weather patterns in a place, and also it may cause weather patterns to be less certain. These unpredicted weather patterns can make it challenging to sustain and grow crops in regions that depend on farming because the expected temperature and rainfall level may no longer be depended on and also it has also been associated with other destructing weather 
events like more persistent and more severe droughts, floods, heavy rainfall, and winter storms (Asian Development Bank, 2009). Climate change is prone to contribute considerably to food insecurity in the forthcoming, by increasing the prices of food, and reducing the production of food. Food may become more valuable as climate change diminishing efforts increase the energy prices (Ramachandran, 2014). In handling food security both the characteristics of malnutrition - starvation and micro-nutrient deficiency, together with excess intake, obese, and plumpness has necessary to be well chosen (FAO et al. 2018). In the past few decades, hidden hunger (sustained across representing Fe, Vit. A, and lack of Zn) aggravated in Africa, while it especially raised in the Asia and Pacific regions (Max Roser et.al, 2021). Elevated levels of atmospheric carbon dioxide $\left(\mathrm{CO}_{2}\right)$ are also expected to lower levels of zinc, iron, and other important nutrients in crops.

\section{Food Demand and Production:}

Due to the increasing population all over the world, the food production needs to be increased. Elevated levels of atmospheric carbon dioxide $\left(\mathrm{CO}_{2}\right)$ are also expected to lower levels of zinc, iron, and other important nutrients in crops (International Food Policy Research Institute, 2019). Farmers worldwide will need to increase crop production, either by increasing the amount of agricultural land to grow crops or by enhancing productivity on existing agricultural lands. There is strong academic consensus that climate change-driven water scarcity, rising global temperatures, and extreme weather will have severe long-term effects on crop yields (Maarten Elferink and Florian Schierhorn, 2016). But due to the prolonged rainfalls, long periods of high temperatures that has caused drought related stress and decreases the productivity of crops. This will build up into a gradual shortage of supplies, leading to mass food shortage (IPCC Chaapter $5)$.

The Intergovernmental Panel On Climate Change Working Group II chapter on Food Security and Food Production Systems destitute new ground by enlarging its focus on the far side the consequences of global climate totally on the production of Agriculture which includes crops, livestock and aquaculture to incorporate a food systems approach further as directive attention to malnourished people (NRCB et.al, 2016). Anyhow, it concentrated mainly on food production systems because of the ubiquity of examinations on thereon topic. It emphasized that a span of developing alteration options survive beyond all food system schemes, not only in production of food, and that aids from inherent development in food processing, packaging, transport, storage, and trade were inadequately analyzed at that time (Science Breakthroughs to Advance Food and Agricultural Research by 2030. Washington).

The proof for fast global climate change (Intergovernmental Panel On Climate Change IV Assessment Report) is engrossing: 
(1) Rise in ocean Level: International lowland rose regarding seventeen $\mathrm{cm}(6.7$ in.) within the last century. The speed within the last decade, however, is regarding doubly that of the previous century.

(2) Rise in international temperature: Most of this heating has existed as of the Seventies, with the twenty warmest years having existed as of 1981 and with all ten of the warmest years occurring since twelve years.

(3) Warming oceans: The oceans have absorbed abundant of the magnified heat, with the highest $700 \mathrm{~m}$ (about 2300 foot.) of ocean showing warming of zero.302॰ F since 1969.

(4) Shrinking ice sheets: The Kalaallit Nunaat and also the Antarctic ice sheets have reduced in mass. information from NASA's Gravity Recovery \& Climate Experiment show Kalaallit Nunaat lost regarding 150-250 cuboidal kilometer of ice per annum between 2002 and 2006, whereas Antarctic continent lost regarding 152 cuboidal kilometer of ice between 2002 and 2005 .

(5) Declining Arctic ocean ice: each the extent and thickness of Arctic ocean ice has lessened quickly over several decades.

(6) Glacial retreat: Glaciers are withdrawing nearly all over round the world - together with within the Alps, Himalayas, Andes, Rockies, Last Frontier and continent.

(7) Ocean acidification: From the start of the economic Revolution, acidity of the surface ocean waters has been magnified by nearly half-hour. The number of carbonic acid gas absorbed by the higher layer of the oceans is increasing by regarding 2 billion tons per annum.

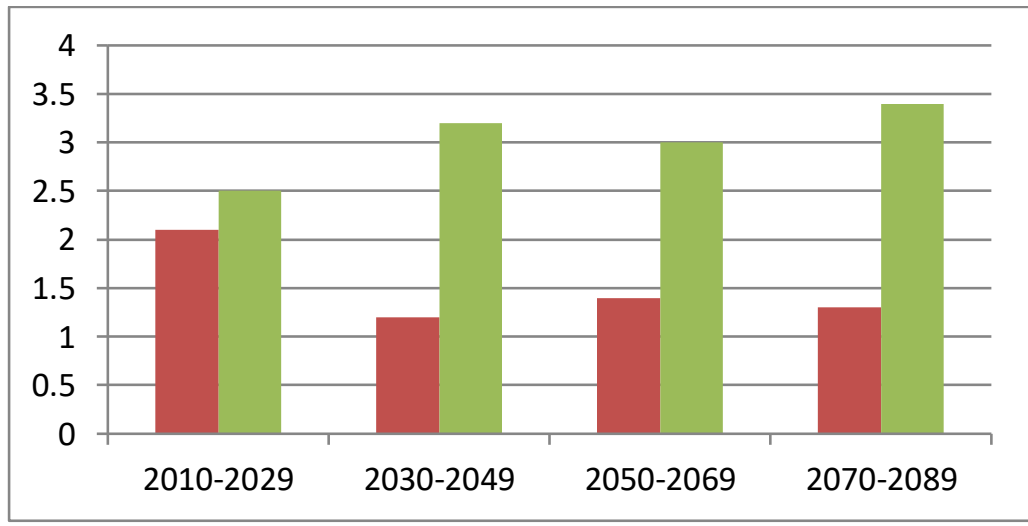

Fig. 1 Outline of projected changes in crop yields, because of temperature change over the twenty first century. The figure includes projections for various emission situations, for tropical and temperate regions, and for adaptation and no-adaptation cases combined. relatively, few 
studies have thought-about impacts on cropping systems for situations wherever world mean temperatures increase by $4^{\circ}$ celsius or additional. For five periods within the close to term and future, information ( $\mathrm{n}=1090)$ ar planned within the 20-year amount on the horizontal axis that features the point of every future projection amount. Changes in crop yields are relative to late20th-century levels. Information for every timeframe adds to 100\%. (C) IPCC, 2014, fifth ASSESSMENT

\section{Impact Of global climate change on Agricultural Crops:}

- (Trudie Dockerty et al.) explored the chance of decoding global climate change impacts info of agricultural landscape in metropolis through GIS based mostly visualizations.

- (Rivington et al.) argued that associate degree Integrated Assessment (IA) approach, combining simulation modeling with thoughtful method involving call manufacturers and different stakeholders, has the potential to come up with credible and relevant assessments of global climate change impacts on farming systems.

- Despite the importance of eutherian to poor individuals and also the magnitude of the changes that square measure probably to befall eutherian systems, the intersection of global climate change and eutherian in developing countries could be a comparatively neglected analysis space. terribly touch is understood concerning the interactions of climate and increasing variability in climate with different drivers of modification in eutherian systems and in broader development trends ( Adger W.N et.al).

- (Thornton et al.) in brief reviewed the literature on global climate change impacts on eutherian and eutherian systems in developing countries. The impact of global climate change on eutherian in terms of amount and quality of feeds, heat stress, water, eutherian diseases and vectors, variety and systems and livelihoods were studied.

\section{Government of India has initiated varied actions to mitigate affects of climate change:}

- Varieties and cultivars that ar tolerant to the abiotic stress ar developed underneath the strategic analysis part of National Initiative on Climate Resilient Agriculture.

- The technology demonstrations aim at enhancing the adjustive capability of the farmers and conjointly to survive with the climate variability within the sensitive districts to attain climate resilient agriculture. underneath National Initiative on Climate Resilient Agriculture, climate resilient technology demonstrations ar enforced in 151 climatically sensitive districts round the country.

- District Agriculture Contingency Plans are ready by the Indian Council of Agricultural analysis-Central Research Institute for Dryland Agriculture, for regarding 648 districts within the country to handle all the adverse climate. 
Impact of the global climate change on Agriculture results in one 5\% loss in India's value

\section{India - Commodity wise impacts}

(from modelling)

negative $\square$ Mixed $\square$ positive

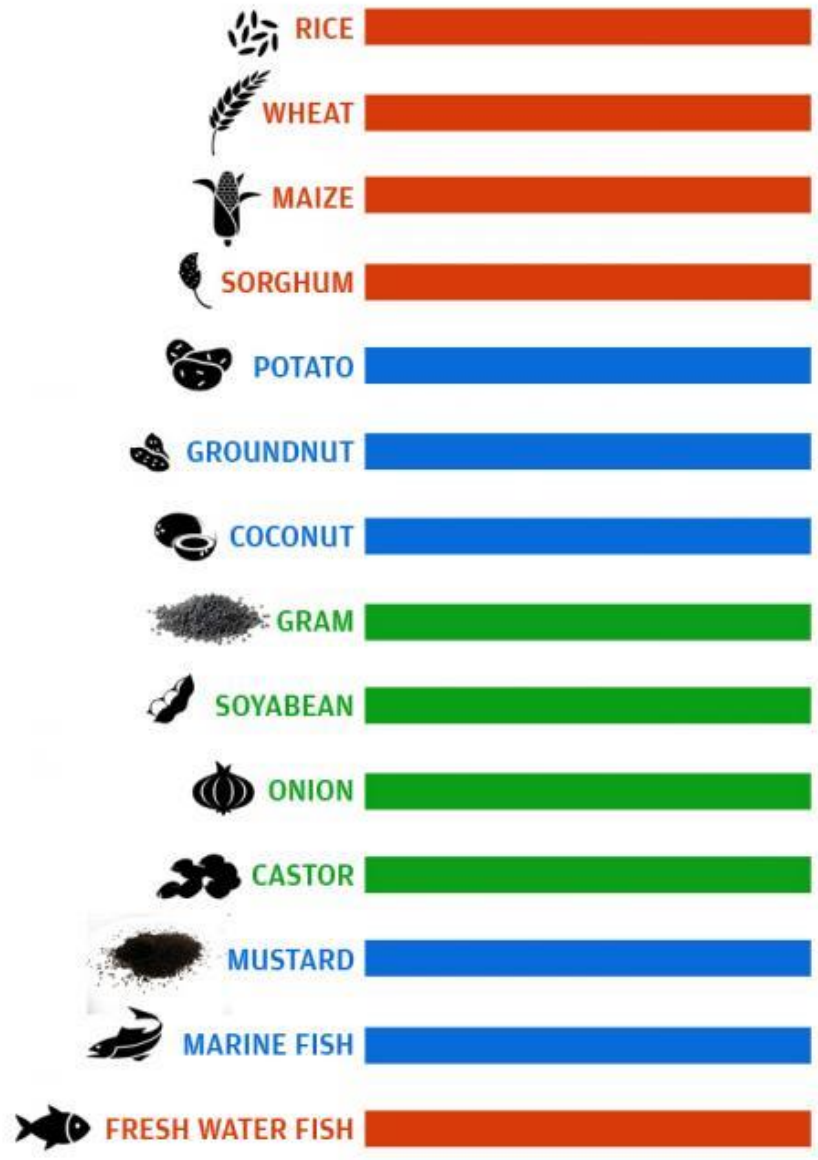

Source: Down To Earth (DTE).

Fig 2: In India due to climate change Rice, wheat, maize, sorghum shows negative Impact. Whereas gram, soybean, castor shows positive impact. 


\section{Impact of the Climate change on Food Security:}

"Food security exists when all people, at all times, have physical and economic access to sufficient, safe and nutritious food that meets their dietary needs and food preferences for an active and healthy life". (World Food Summit, 1996)

Food security is one of the main distress associated with the climate change. Changes in the climate have an effect on the food security in complicated ways. It shows an impact on the crops, livestock, forestry, fisheries and aquaculture, and can cause serious social and economic consequences in the form of reduced incomes, eroded livelihoods, trade disruption and adverse health impacts (Moors E. et al., 2013). However, it is important to note that the net impact of climate change depends not only on the extent of the climatic shock but also on the substantive vulnerabilities (FAO, 2016). According to the FAO (2016), both the biophysical and the social vulnerabilities decide the net impact of the climate change on food security.

Much of the literature on the impact of change in the climate on food security, although, has focused on just one aspect of the food security, i.e., food production. Climate change presents an additional stress on India's long-term food security challenges as it impacts the food production in several ways. For one, it may cause compelling increases in inter-annual and intra-seasonal variability of the monsoon rainfall. According to World Bank estimates, based on the International Energy Agency's current policy scenario and other energy sector economic models, for a global mean warming of $4^{\circ}$ Celsius, there will be a $10 \%$ increase in annual mean monsoon intensity and a $15 \%$ increase in year-to-year variability in the monsoon precipitation. Indian agriculture, and thereby India's food production, is highly liable to climate change largely because the sector continues to be highly sensitive to the variability in monsoon. Ultimately, about $65 \%$ of the India's cropped area is under rain-fed. Lobell et.al (2012) found that wheat growth in Northern India is highly sensitive to temperatures greater than $34^{\circ} \mathrm{C}$. The IPCC report of 2007 sounded similar concerns on wheat yield: a $0.5^{\circ}$ celsius rise in the winter temperature is prone to reduce the wheat yield by 0.45 tons per hectare in India. 


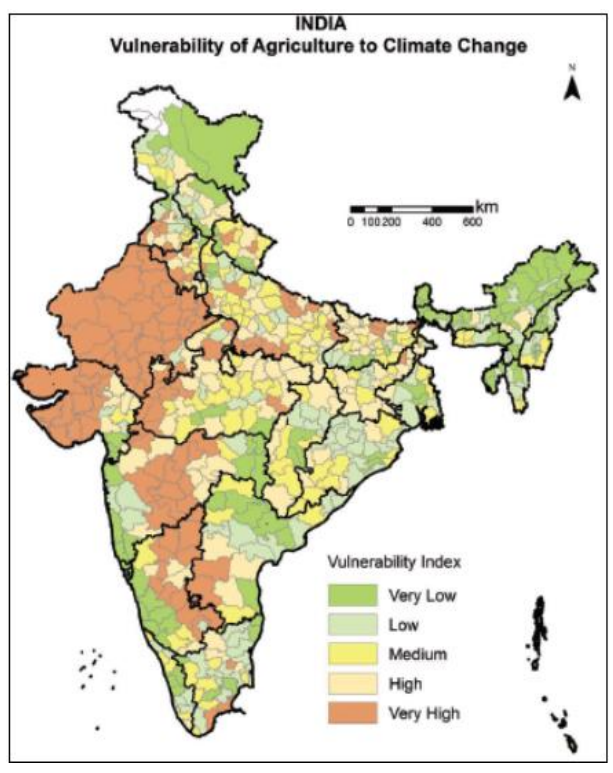

Source: Rama Rao C. A. et al., "Atlas on Vulnerability of Indian Agriculture to Climate Change", Central Research Institute for Dry land Agriculture, Hyderabad, 2013

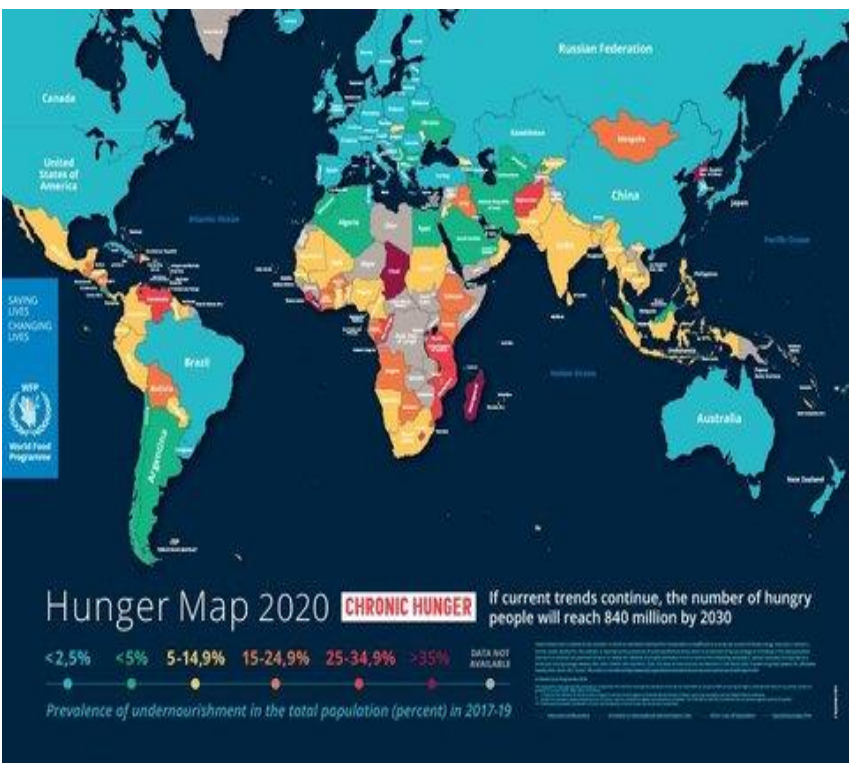

Source: SOFI Report 2020

\section{Impact of the worldwide temperature change on Food Security:}

"Food security exists once all individuals, within the slightest degree times, have physical and economic access to decent, safe and alimentary food that meets their dietary wants and food preferences for an energetic and healthy life". (World Food Summit, 1996) Food security is one in every of the foremost distress associated with the worldwide global climate change.

Amendment within the climate has an effect on the food security in difficult ways during which. It shows an impact on the crops, livestock, forestry, fisheries and cultivation, and should cause serious social and economic consequences within the kind of reduced incomes, worn livelihoods, trade disruption and adverse health impacts. However, it is necessary to note that net impact of worldwide temperature change depends not solely on the extent of the climatically shock however conjointly on the substantive vulnerabilities. In keeping with the global organization agency (2016), each the biophysical and thus the social vulnerabilities decide net impact of the worldwide global climate change on food security. Much of the literature on the impact of amendment within the climate on food security, although, has centered on only 1 side of the food security, i.e., food production. Global temperature change presents an additional stress on India's 
semi permanent food security challenges because it impacts the food production in some ways within which.

For one, it should cause compelling will increase in inter-annual and intra-seasonal variability of the monsoon downfall. in step with International Bank for Reconstruction and Development estimates, supported the International Energy Agency's current policy situation and different energy sector economic models, for a worldwide mean warming of $4^{\circ}$ Celsius, there will be a tenth increase in annual mean monsoon intensity and a V-day increase in year-to-year variability within the monsoon precipitation. Indian agriculture, and thereby India's food production, is extremely liable to global global climate change mostly as a results of the planet continues to be sensitive to the variability in monsoon. Ultimately, concerning sixty fifth of the India's cropped space is beneath rain-fed. Lobell et.al (2012) found that wheat growth in Northern Bharat is extremely sensitive to temperatures bigger than $34^{\circ} \mathrm{C}$.

The IPCC report of 2007 measured similar considerations on wheat yield: a zero. $5^{\circ}$ celsius rise within the winter temperature is susceptible to reduce the wheat yield by zero. 45 tons per area unit in Bharat.

\section{STRATEGIES TO MITIGATE IMPACT OF CLIMATE CHANGE IN AGRICULTURE AND FOOD SECURITY:}

The different adaptation strategies being formulated and developed at individual, organizational, and institutional level to avert the negative impacts of the climate change are as under-

- Effective climate-smart agricultural production

- Livelihoods diversification/alternatives

- Resources decentralization under local governance

- Fossil fuel alternatives such as biofuels

- Infrastructure development

- Mass awareness toward climate change

- Natural hazard anticipation and early warning systems

- Insurance schemes and policy suggestions

- Research and development activities for development \& dissemination of crop varieties suitably adapted to local areas

- Wise applications of genetic materials

- Vernacular knowledge use/gender considerations

- Promotion of integrated farming systems and agroforestry

- Improvement in infrastructure facilities: water harvesting techniques, storage and smallscale irrigation, etc. 
International Journal of Agriculture and Environmental Research

ISSN: 2455-6939

Volume: 07, Issue: 03 "May-June 2021"

- Improvement in water and soil management practices

- Adaptation to livelihood strategies and farming operation systems.

\section{CONCLUSION}

The 3rd Assessment Report revealed by the Intergovernmental Panel On Climate Change in 2001 states, 'there is new and stronger proof that almost all of the warming discovered over the last fifty years is due to human activities'. There square measure several convincing facts for the impact of global climate change on numerous parts of part like air, water, plants, animals and people in general, which, if not acted upon, might cause catastrophes. Climate modification influences the air quality, will increase the dominance of blue-green algae in water bodies, and affects quality of the drinkable, a modification within the hydrological cycle, inferring on the watercourse geophysics, vary limits of plant species, adverse impacts on life. Climate change, the result of "Global Warming" has began to reveal its outcomes worldwide. the first determinant of agricultural productivity is "climate" that bears the direct impact on international food production. though life cycle of grain and seed crops square measure possible to progress a lot of rapidly; however with increasing temperatures and variable downfall, crops might begin to expertise failure, significantly underneath low and variable precipitation patterns. Thanks to modification in climate, northward shifting of plant species, range, and pastures, cropland weeds is adversely touching placental operations, grazing and crops. Increase in close temperature of the world is probably going to hamper production of the placental throughout summer season. Ruminants square measure far more inclined, as they're not provided shelter to beat negative effects of the global climate change. because the climate of a selected country/region regulates the character and properties of the crop and vegetation, agriculture sector is that the a lot of liable to global climate change. period of the many crops together with their various yield is probably going to be reduced thanks to increase in mean seasonal temperature. However, the adverse effects of climate changes square measure low for economic activities together with agriculture that make sure the convenience and accessibility of food to folks.

\section{REFERENCES AND FURTHER READING}

- https://www.nationalgeographic.org/encyclopedia/climate-change/

○ https://www.google.com/search?q=climate+change+definition\&rlz=1C1CHBF_enIN801 IN801\&oq $=$ climate + change $+\& a q s=$ chrome $2.69 \mathrm{i} 57 \mathrm{j} 0 \mathrm{j} 0 \mathrm{i} 43312 \mathrm{j} 0 \mathrm{j} 69 \mathrm{i} 61 \mathrm{j} 69 \mathrm{i} 6012.5501 \mathrm{j} 0 \mathrm{j} 7$ \&sourceid $=$ chrome \&ie $=$ UTF- 8

○ Porter, J.R., L. Xie, A.J. Challinor, K. Cochrane, S.M. Howden, M.M. Iqbal, D.B. Lobell, $\&$ Travasso, M.I. (2014). Food security and food production systems. In: Climate Change 2014: Impacts, Adaptation, and Vulnerability.Part A: Global and Sectoral Aspects. Contribution of Working Group II to the Fifth Assessment Report of the 
International Journal of Agriculture and Environmental Research

ISSN: 2455-6939

Volume: 07, Issue: 03 "May-June 2021"

Intergovernmental Panel Co Climate

https://scholar.google.com/scholar lookup?title=Impact $\% 20$ of $\% 20$ climate $\% 20$ change $\% 2$ 0on\%20pests\%20and\%20diseases\%20in\%20Australasia\&author=RW.\%20Sutherst\&aut hor=GF. \%20Maywald \&journal=Search $\% 20 \% 28$ Sydney\%29\&volume $=21 \&$ pages $=230$ 232\&publication year $=1990$

○ Wheeler, T., \& Von Braun, J. (2013). Climate change impacts on global food security. Science, 341(6145), 508-513.

- https://www.futurelearn.com/info/courses/climate-smart-agriculture/0/steps/26565\#

- https://pib.gov.in/newsite/PrintRelease.aspx?relid=191979\#: :text=Agriculture\%20sector \%20in\%20India\%20is, and \%20changes\%20in\%20water\%20availability.

- Porter, J.R., L. Xie, A.J. Challinor, K. Cochrane, S.M. Howden, M.M. Iqbal, D.B. Lobell, and M.I. Travasso, 2014: Food security and food production systems. Clim. Chang. 2014 Impacts, Adapt. Vulnerability. Part A Glob. Sect. Asp. Contrib. Work. Gr. II to Fifth Assess. Rep. Intergov. Panel Clim. Chang., 2, 485-533, doi:10.1111/j.17284457.2009.00312.x.

- Porter, J.R., M. Howden, and P. Smith, 2017: Considering agriculture in IPCC assessments. Nat. Clim. Chang., 7, 680-683, doi:10.1038/nclimate3404.

○ https://www.bloomberg.com/graphics/2020-solving-the-global-food-problem/

- https://pib.gov.in/newsite/PrintRelease.aspx?relid=191979\#: :text=Agriculture\%20sector $\% 20$ in $\% 20$ India\%20is,and $\% 20$ changes $\% 20$ in $\% 20$ water\%20availability.

- Robert Mendelsohn. Chapter 60 past climate change impacts on agriculture.Handbook of Agricultural Economics 2007;3:3009-31.

- Tubiello FN, Gunther Fischera. Reducing climate change impacts on agriculture: global and regional effects of mitigation, 2000-2080. TechnologicalForecasting and Social Change 2007;74(7):1030-56.

- Trudie Dockerty, Andrew Lovett, Gilla Sunnenberg, Katy Appleton, Martin Parry. Visualizing the potential impacts of climate change on rural landscapes.Computers, Environment and Urban Systems 2005;29(3):297-320.

- Rivington M, Matthew KB, Bellocchi G, Buchan K, Stocklec CO, Donatelli M.An integrated assessment approach to conduct analysis of climate change impacts on wholefarm systems. Environmental Modelling and Software 2007;22(2):202-10.

- https://www.downtoearth.org.in/news/agriculture/climate-change-causes-about-1-5-percent-loss-in-india-s-gdp-57883

- Chakraborty S, Tiedemann AV, Teng PS (2000) Climate change and air pollution: potential impact on plant diseases. Environ Pollut 108:317-326

○ Coakley SM, Scherm H, Chakraborty S (1999) Climate change and plant disease management. Annu Rev Phytopathol 37:399-426 
International Journal of Agriculture and Environmental Research

ISSN: 2455-6939

Volume: 07, Issue: 03 "May-June 2021"

- Sutherst RW, Maywald GF (1990) Impact of climate change on pests and diseases in Australasia. Search (Sydney) 21:230-232

- Reilly, John. "Climate Change, Global Agriculture, and Regional Vulnerability." Unpublished manuscript presented at the International Workshop on Climate Change, Laxenburg, Austria, 1996

○ Easterling, William E., III; Crosson, Pierre R.; Rosenberg, Norman J.; McKenney, Mary S.; Katz, Laura A. and Lemon, Kathleen M. "Agricultural Impacts of and Responses to Climate Change in the Missouri-IowaNebraska-Kansas (MINK) Region." Climatic Change, June 1993, 24(1-2), pp. 23-61.

- International Panel on Climate Change (IPCC). Climate change 1995: The science of climate change. Cambridge: Cambridge University Press, 1996.

- Parry et al., "Climate Change and Hunger: Responding to the Challenge", Rome: World Food Programme, 2009, http://www.preventionweb.net/files/12007 wfp212536.pdf

- "Rome Declaration on World Food Security", Rome, November 13-7, 1996. http://www.fao.org/docrep/003/w3613e/w3613e00.HTM.

- "Climate change and food security: risks and responses", Food and Agriculture Organisation, 2016. http://www.fao.org/3/a-i5188e.pdf

○ "Turn Down the Heat: climate Extremes, regional impacts, and the case for resilience", World Bank,2013. http://www.worldbank.org/content/dam/Worldbank/document/Full_Report_Vol_2_T urn_Down_The_Heat_\%20Climate_Extremes_Regional_Impacts_Case_for_Resilienc e_Print \%20version_FINAL.pdf

○ Chan, W. H., Mak, Y. L., Wu, J. J., Jin, L., Sit, W. H., ... Murphy, M. B. (2011). Spatial distribution of ciguateric fish in the Republic of Kiribati. Chemosphere, 84(1), 117123. Chartzoulakis, K., \& Bertaki, M. (2015)

- Bharucha, Z., \& Pretty, J. (2010). The roles and values of wild foods in agricultural systems. Philosophical Transactions of the Royal Society B: Biological Sciences, 1554(365), 29132926. Brander, K. (2015). Improving the reliability of fishery predictions under climate change.

- Rama Rao C. A. et al., "Atlas on Vulnerability of Indian Agriculture to Climate Change", Central Research Institute for Dry land Agriculture, Hyderabad, 2013.

- Yohe et al., "Perspectives on climate change and sustainability", in Climate Change 2007: Impacts, Adaptation and Vulnerability. Contribution of Working Group II to the Fourth Assessment Report of the Intergovernmental Panel on Climate Change, 
International Journal of Agriculture and Environmental Research

ISSN: 2455-6939

Volume: 07, Issue: 03 "May-June 2021"

eds. M. L. Parry et al. (UK: Cambridge University Press, 2007), 811841. https://www.ipcc.ch/pdf/assessment-report/ar4/wg2/ar4-wg2-chapter20.pdf

- W. E. Easterling et al., "Food, fibre and forest products", in Climate Change 2007: Impacts, Adaptation and Vulnerability. Contribution of Working Group II to the Fourth Assessment Report of the Intergovernmental Panel on Climate Change, eds. M. L. Parry et al. (UK: Cambridge University Press, 2007), 469506, http://www.ipcc.ch/pdf/assessment-report/ar4/wg2/ar4 wg2 full report.pdf

○ "Turn Down the Heat: climate Extremes, regional impacts, and the case for resilience", World Bank, 2013. http://www.worldbank.org/content/dam/Worldbank/document/Full Report Vol 2_Turn

Down The Heat \%20Climate Extremes Regional Impacts Case for Resilience Pr $\underline{\text { int } \% 20}$

version FINAL.pdf

- S. K. Goyal and P. Singh, "Demand Versus Supply of Food grains in India: Implications to Food Security", Paper prepared for presentation at the $13^{\text {th }}$ Inte

○ rnational Farm Management Congress, Wageningen, The Netherlands, July 2002. http://ageconsearch.umn.edu/bitstream/6948/2/cp02go02.pdf

- IPCC, 2013. Climate change 2013: the physical science basis. In: Stocker, T.F., Qin, D., Plattner, G.-K., Tignor, M., Allen, S.K., Boschung, J., Nauels, A., Xia, Y., Bex, V.,Midgley, P.M. (Eds.), Contribution of Working Group I to the Fifth Assessment Report of the Intergovernmental Panel on Climate Change. Cambridge University Press, Cambridge, United Kingdom and New York, NY, USA 1535 pp. http://www.climatechange2013.org/images/report/WG1AR5_ALL_FINAL.pdf.

○ Jagadish, K.S.V., Murty, M.V., Quick, W.P., 2015. Rice responses to rising temperatures-challenges, perspectives and future directions. Plant Cell Environ. 38, 1686-1698. https://doi.org/10.1111/pce.12430.

- Lanning, S.B., Siebenmorgen, T.J., Counce, P.A., Ambardekar, A.A., Mauromoustakos, A.,2011. Extreme nighttime air temperatures in 2010 impact rice chalkiness and milling quality. Field Crops Res. 124, 132-136.

○ Laza, M.R.C., Sakai, H., Cheng, W., Tokida, T., Peng, S., Hasegawa, T., 2015. Differential response of rice plants to high night temperatures imposed at varying developmental phases. Agric. For. Meteorol. 209-210, 69-77.

○ Lei, G., Zhang, H.Y., Wang, Z.H., Wei, L.X., Fu, P., Song, J.B., Fu, D.H., Huang, Y.J., Liao, J.L., 2018. High nighttime temperature induces antioxidant molecule perturbations in heat-sensitive and heat-tolerant coisogenic rice (Oryza sativa) strains. J. Agric. Food Chem. 66, 12131-12140. 
International Journal of Agriculture and Environmental Research

ISSN: 2455-6939

Volume: 07, Issue: 03 "May-June 2021"

○ Li, Q., Sun, S.S.M., Yuan, D., Yu, H., Gu, M., Liu, Q., 2009. Validation of candidate reference genes for the accurate normalization of real-time quantitative RT-PCR data in rice during seed development. Plant Mol. Biol. Rep. 28, 49-57.

○ Liao, J.L., Zhou, H.W., Zhang, H.Y., Zhong, P.A., Huang, Y.J., 2014. Comparative proteomic analysis of differentially expressed proteins in the early milky stage of rice grains during high temperature stress. J. Ex

○ Liao, J.L., Zhou, H.W., Peng, Q., Zhong, P.A., Zhang, H.Y., He, C., Huang, Y.J., 2015. Transcriptome changes in rice (Oryza sativa L.) in response to high night temperature stress at the early milky stage. BMC Genomics 16,18 . https://doi.org/10.1186/s12864015-1222-0.

- Lobell, D.B., Burke, M.B., Tebaldi, C., Mastrandrea, M.D., Falcon, W.P., Naylor, R.L.,2008. Prioritizing climate change adaptation needs for food security in 2030. Science 319, 607-610. https://doi.org/10.1126/science.1152339.

○ Mishra, S., Singh, B., Misra, P., Rai, V., Singh, N.K., 2016. Haplotype distribution and association of candidate genes with salt tolerance in Indian wild rice germplasm. Plant Cell Rep. 35, 2295-2308. https://doi.org/10.1007/s00299-016-2035-6.

○ Xiao, N., Gao, Y., Qian, H., Gao, Q., Wu, Y., Zhang, D., Zhang, X., Yu, L., Li, Y., Pan, C.,Liu, G., Zhou, C., Jiang, M., Huang, N., Dai, Z., Liang, C., Chen, Z., Chen, J., Li, A.,2018. Identification of genes related to cold tolerance and a functional allele that confers cold tolerance. Plant Physiol. 177, 1108-1123. https://doi.org/10.1104/pp.18.00209.

○ Peng, S., Huang, J., Sheehy, J.E., Laza, R.C., Visperas, R.M., Zhong, X., Centeno, G.S.,Khush, G.S., Cassman, K.G., 2004. Rice yields decline with higher night temperature from global warming. Proc. Natl. Acad. Sci. U. S. A. 101, 9971-9975. https://doi.org/10.1073/pnas.0403720101.

- Shi, P., Zhu, Y., Tang, L., Chen, J., Sun, T., Cao, W., Tian, Y., 2016. Differential effects of temperature and duration of heat stress during anthesis and grain filling stages in rice. Environ. Exp. Bot. 132, 28-41. https://doi.org/10.1016/j.envexpbot.2016.08.006.

○ Thirumalai, K., DiNezio, P.N., Okumura, Y., Deser, C., 2017. Extreme temperatures in Southeast Asia caused by El Nino and worsened by global warming. Nat. Commun. 8,15531. https://doi.org/10.1038/ncomms15531.

- Trapnell, C., Williams, B.A., Pertea, G., Mortazavi, A., Kwan, G., van Baren, M.J. Salzberg, S.L., Wold, B.J., Pachter, L., 2010. Transcript assembly and quantification by RNA-Seq reveals unannotated transcripts and isoform switching during cell differentiation.Nat. Biotechnol. 28, 511-515. https://doi.org/10.1038/nbt.1621.

○ Van den Berge, K., Soneson, C., Robinson, M.D., Clement, L., 2017. StageR: a general stage-wise method for controlling the gene-level false discovery rate in differential 
International Journal of Agriculture and Environmental Research

ISSN: 2455-6939

Volume: 07, Issue: 03 "May-June 2021"

expression and differential transcript usage. Genome Biol. 18, 151. https://doi.org/10.1186/s13059-017-1277-0.

○ Zhao, C., Xie, J., Li, L., Cao, C., 2017. Comparative transcriptomic analysis in paddy rice under storage and identification of differentially regulated genes in response to high temperature and humidity. J. Agric. Food Chem. 65, 8145-8153. https://doi.org/10.1021/acs.jafc.7b03901.]

○ G_erard, P. R., E. K. Klein, F. Austerlitz, J. F. Fern_andez-Manjarr_es, and N. FrascariaLacoste. 2006. Assortative mating and differential male mating success in an ash hybrid zone population. BMC Evol. Biol. 6:96.

○ Goldberg, E. E., and R. Lande. 2006. Ecological and reproductive character displacement on an environmental gradient. Evolution 60:1344-1357.

○ Kruuk, L. E. B., S. J. E. Baird, K. S. Gale, and N. H. Barton. 1999. A comparison of multilocus clines maintained by environmental adaptation or by selection against hybrids.Genetics 153:1959-1971.

○ Alston, J.M., Beddow, J.M., Pardey, P.G., 2009. Agricultural research, productivity, and food prices in the long run. Science 325, 1209-1210.

○ Fan, M., Lal, R., Cao, J., Qiao, L., Su, Y., Jiang, R., Zhang, F., 2013. Plant-based assessment of inherent soil productivity and contributions to China's cereal crop yield increase since. PLoS One 8 (9), e74617. FAOSTAT, 2013. Available on http://faostat3.fao.org/home/index.html.

○ Ray, D.K., Ramankutty, N., Mueller, N.D., West, P.C., Foley, J.A., 2012. Recent patterns of crop yield growth and stagnation. Nat. Commun. 3, 1293.

○ Xiong, W., Holman, I.P., You, L., Yang, J., Wu, W., 2014a. Impacts of observed growing- season warming trends since on crop yields in China. Reg. Environ. Change 14, 6-7.

○ Xiong, W., Balkovi9c, J., van der Velde, M., Zhang, X., Izaurralde, R.C., Skalsky, R., Lin, E., Mueller, N., Obersteiner, M., 2014. A calibration procedure to improve global rice yield simulations with EPIC. Ecol. Model. 273, 128-139.

○ Wild, M., Gilgen, H., Roesch, A., Ohmura, A., Long, C.N., Dutton, E.G., Forgan, B., Kallis, A., Russak, V., Tsvetkov, A., 2005. From dimming to brightening: decadal changes in solar radiation at earth's surface. Science 308, 847-850

○ Liu, Z., Li, Z., Tang, P., Li, Z., Wu, W., Yang, P., You, L., Tang, G., 2013b. Change analysis of rice area and production in China during the past three decades. J. Geogr. Sci. 23 (6), 1005-1018.

○ Liu, Z., Hubbard, K.G., Lin, X., Yang, X., 2013a. Negative effects of climate warming on maize yield are reversed by the changing of sowing date and cultivar section in Northeast China. Glob. Change Biol. 19, 3481-3492. 
International Journal of Agriculture and Environmental Research

ISSN: 2455-6939

Volume: 07, Issue: 03 "May-June 2021"

○ Van der Velde, M., Folberth, C., Balkovic, J., Ciais, P., Fritz, S., Janssens, I.A., Obersteiner, M., See, L., Skalský, R., Xiong, W., Peñuelas, J., 2014. African crop yield reduction due to increasingly unbalanced nitrogen and phosphorus consumption. Glob. Change Biol. 20, 1278-1288 You, L., Rosegrant, M.W., Wood, S., Sun, D., 2009. Impact of growing season temperature on wheat productivity in China. Agric. Forest Meteorol. $149,1009-1014$.

- Pohlert, T., 2004. Use of empirical global radiation models for maize growth simulation. Agric. Forest Meteorol. 126, 47-58.

- Tao, F., Yokozawa, M., Liu, J., Zhang, Z., 2008. Climate-crop yield relationships at provincial scales in China and the impacts of recent climate trends. Climate Res. 38, 8394.

○ Kahrl, F., Li, Y., Su, Y., Tennigkeit, T., Wilkes, A., Xu, J., 2010. Greenhouse gas emissions from nitrogen fertilizer use in China. Environ. Sci. Policy 13, 688- 694.

○ Cammarano, D., Rötter, R.P., Asseng, S., Ewert, F., Wallach, D., Martre, P., Hatfield, J.L., Jones, J.W., Rosenzweig, C., Ruane, A.C., Boote, K.J., Thorburn, P.J., Kersebaum, K.C., Aggarwal, P.K., Angulo, C., Basso, B., Bertuzzi, P., Biernath, C., Brisson, N.,Challinor, A.J., Doltra, J., Gayler, S., Goldberg, R., Heng, L., Hooker, J.E., Hunt, L.A.,Ingwersen, J., Izaurralde, R.C., Müller, C., Kumar, S.N., Nendel, C., O'Leary, G.,Olesen, J.E., Osborne, T.M., Priesack, E., Ripoche, D., Steduto, P., Stöckle, C.O.,Stratonovitch, P., Streck, T., Supit, I., Tao, F., Travasso, M., Waha, K., White, J.W.,Wolf, J., 2016. Uncertainty of wheat water use: simulated patterns and sensitivity to temperature and CO2. Field Crops Res. 198, 80-92.

○ Cheng, W., Sakai, H., Yagi, K., Hasegawa, T., 2010. Combined effects of elevated [CO2] and high night temperature on carbon assimilation, nitrogen absorption, and the allocations of $\mathrm{C}$ and $\mathrm{N}$ by rice (oryza sativa L.). Agr. For. Meteorol. 150 (9),1174-1181.

○ Dong, W., Chen, J., Zhang, B., Tian, Y., Zhang, W., 2011. Responses of biomass growth and grain yield of midseason rice to the anticipated warming with FATI facility in East China. Field Crops Res. 123 (3), 259-265.

- Fuhrer, J., 2003. Agroecosystem responses to combinations of elevated CO2, ozone, and global climate change. Agr. Ecosyst. Environ. 97 (1), 1-20.

- Horie, T., Baker, J.T., Nakagawa, H., Matsui, T., Kim, H.Y., 2000. Crop ecosystem responses to climatic change: rice. In: Reddy, K.R., Hodges, H.F. (Eds.), Climate Change and Global Crop Productivity. CAB International, Wallingford, UK, pp. 81-106.

○ Hu, H.-W., Macdonald, C.A., Trivedi, P., Anderson, I.C., Zheng, Y., Holmes, B., Bodrossy, L., Wang, J.-T., He, J.-Z., Singh, B.K., 2016. Effects of climate warming and elevated $\mathrm{CO} 2$ on autotrophic nitrification and nitrifiers in dryland ecosystems. Soil. Biol.Biochem. 92, 1-15. 
International Journal of Agriculture and Environmental Research

ISSN: 2455-6939

Volume: 07, Issue: 03 "May-June 2021"

○ Okada, H., Sakai, H., Tokida, T., Usui, Y., Nakamura, H., Hasegawa, T., 2014. Elevated temperature has stronger effects on the soil food web of a flooded paddy than does $\mathrm{CO} 2$. Soil. Biol. Biochem. 70, 166-175.

- McGrath, J.M., Lobell, D.B., 2013. Reduction of transpiration and altered nutrient allocation contribute to nutrient decline of crops grown in elevated $\mathrm{CO} 2$ concentrations.Plant Cell. Environ. 36 (3), 697-70

○ Rustad, L., Campbell, J., Marion, G., Norby, R., Mitchell, M., Hartley, A., Cornelissen, J., Gurevitch, J., 2001. A meta-analysis of the response of soil respiration, net nitrogen mineralization, and aboveground plant growth to experimental ecosystem warming. Oecologia 126 (4), 543-562.

- Wheeler, T., von Braun, J., 2013. Climate change impacts on global food security. Science 341 (6145), 508-513.

- Serge Planton, Michel Deque, Fabrice Chauvin, Laurent Terray. Expected impacts of climate change on extreme climate events. Comptes Rendus Geosciences 2008;340(910):564-74.

- Anisimov OA, Shiklomanov NI, Nelson FE. Global warming and active-layer thickness: results from transient general circulation models. Global and Planetary Change 1997;15(3-4):61-77.

- Bershadskii A. Transitional solar dynamics and global warming. Physics A:Statistical Mechanics and its Application 2009;388(15-16):3213-24.

- Monirul Qader Mirza M. Global warming and changes in the probability of occurrence of floods in Bangladesh and implications. Global Environmental Change 2002;12(2):12738.

- Mohammed Fazlul Karim, Nobuo Mimura. Impact of climate change and sealevel rise on cyclonic storm surge floods in Bangladesh. Global Environmental Change 2008;18(3):490-500.

- Susanne Becken. Harmonizing climate change adaptation and mitigation: the case of tourist resorts in Fiji. Global Environmental Change Part A 2005;15(4):381-93.

- Koetse MJ, Piet Rietveld. The impact of climate change and weather on transport: an overview of empirical findings. Transportation Research Part D: Transport and Environment 2009;14(3):205-21.

- Tubiello FN, Gunther Fischera. Reducing climate change impacts on agriculture: global and regional effects of mitigation, 2000-2080. Technological Forecasting and Social Change 2007;74(7):1030-56.

- Chakraborthy S, Tiedemann AV, Teng PS. Climate change: potential impact on plant diseases. Environmental Pollution 2000;108(3):317-26. 
International Journal of Agriculture and Environmental Research

ISSN: 2455-6939

Volume: 07, Issue: 03 "May-June 2021"

- Gunther F, Tubielloa FN, van Velthuizena H, Wiberga DA. Climate change impacts on irrigation water requirements: effects of mitigation, 1990-2080.Technological Forecasting and Social Change 2007;74(4):1083-107.

- Thornton PK, Van de Steeg J, Notenbaert A, Herrero M. The impacts of climate change on livestock and livestock systems in developing countries: a review of what we know and what we need to know. Agricultural Systems 2009;101(3):13-27.

- Honjo K. R\&D for technology to solve global warming. Journal of Materials Processing Technology 1996;59(3):218-20.

- Jenkins TN. Democratising the global economy by ecologising economies: the example of global warming. Ecological Economics 1996;16(3):227-38.

- Adil Najam, Rahman AA, Saleemul Haq, Youba Sokona. Integrating sustainable development into the fourth assessment report of the Intergovernmental Panel on Climate Change( IPCC). Climate Policy 2003;3(1):S9-17.

○ Peter Nijkamp, Shunli Wang, Hans Kremers. Modeling the impacts of international climate change policies in a CGE context: the use of the GTAPE model. Economic Modeling 2005;22(6):955-74.

- Tol RSJ, Roda Verheyen. State responsibility and compensation for climate change damages - a legal and economic assessment. Energy Policy 2004;32(9):1109-30.

- Moss RH. Avoiding 'dangerous' interference in the climate system: the roles of values, science and policy. Global Environment Change 1995;5(1):3-6.

- Sanden BA, Christian A. Near-term technology policies for long-term climate targetseconomy wide versus technology specific approaches. Energy Policy 2005;33(12):155776

- Khanna N, Chapman D. Energy efficiency and petroleum depletion in climate change policy. Advances in the Economics of Environmental Resources 2001;3:239-64.

- Xinsheng Liu, Arnold Vedlitza, Letitia Alstona. Regional news portrayals of global warming climate change. Environmental Science \& Policy 2008;11(5):379-93.

- Katarina Larsen, Ulrika Gunnarsson-Osling. Climate change scenarios and citizenparticipation: mitigation and adaptation perspectives in constructing sustainable futures. Habitat International 2009;33(3):260-6.

- Nicholls RJ, Lowe JA. Benefits of mitigation of climate change for coastal areas. Global Environmental Change 2004;14(3):229-44.

- Hamin EM, Nicole Gurran. Urban form and climate change: balancing adaptation and mitigation in the U.S. and Australia. Habitat International 2009;33(3):238-45.

- Hadi Dowlatabadi. Sensitivity of climate change mitigation estimates to assumption about technical change. Energy Economics 1998;20(5-6):473-93. 
International Journal of Agriculture and Environmental Research

ISSN: 2455-6939

Volume: 07, Issue: 03 "May-June 2021"

- Valentina Bosetti, Carlo Carraro, Massimo Tavoni. Climate change mitigation strategies in fast-growing countries: the benefits of early action. Energy Economics 2009;31(2):S144-51.

○ Teeter, K. C., B. A. Payseur, L. W. Harris, M. A. Bakewell, L.M. Thibodeau, J. E. O'Brien, et al. 2008. Genome-wide patterns of gene flow across a house mouse hybrid zone.Genome Res. 18:67-76.

- Thomas, C. D. 2010. Climate, climate change and range boundaries. Divers. Distrib. 16:488-495.

- Scriber, J. M. 2011. Impacts of climate warming on hybrid zone movement: geographically diffuse and biologically porous "species borders". Insect Sci. 18:121-159.

- Taylor, E. B., J. W. Boughman, M. Groenenboom, M.Sniatynski, D. Schluter, and J. L. Gow. 2006. Speciation in reverse: morphological and genetic evidence of the collapse of a three-spined stickleback species pair. Mol. Ecol. 15:343-355.

○ Hellmann, J.J., J.E. Byers, B.G. Bierwagen, and J.S. Dukes, 2008: Five potential consequences of climate change for invasive species. Conserv. Biol., 22, 534-543, doi:10.1111/j.1523-1739.2008.00951.x.

- Balmford, A. et al., 2018: The environmental costs and benefits of high-yield farming. Nat. Sustain., 1, 477, doi:10.1038/s41893-018-0138-5.

- Smith, P., 2013: Delivering food security without increasing pressure on land. Glob. Food Sec., 2, 18-23, doi:10.1016/j.gfs.2012.11.008.

○ Tilman, D., C. Balzer, J. Hill, and B.L. Befort, 2011: Global food demand and the sustainable intensification of agriculture. Proc. Natl. Acad. Sci. U.S.A., 108, 2026020264, doi:10.1073/pnas.1116437108.

○ Briske, D.D. et al., 2015: Climate-change adaptation on rangelands: Linking regional exposure with diverse adaptive capacity. Front. Ecol. Environ., 13, 249-256, doi:10.1890/140266.

○ Smith, P., M. Bustamante, H. Ahammad, H. Clark, H. Dong, E.A. Elsiddig, H. Haberl, R. Harper, J. House, M. Jafari, O. Masera, C. Mbow, N.H. Ravindranath, C.W. Rice, C. Robledo Abad, A. Romanovskaya, F. Sperling, and F. Tubiello, 2014: Agriculture, Forestry and Other Land Use (AFOLU). Climate Change 2014: Mitigation of Climate Change. Contribution of Working Group III to the Fifth Assessment Report of the Intergovernmental Panel on Climate Change, [Edenhofer, O., R. Pichs-Madruga, Y. Sokona, E. Farahani, S. Kadner, K. Seyboth, A. Adler, I. Baum, S. Brunner, P. Eickemeier, B. Kriemann, J. Savolainen, S. Schlömer, C. von Stechow, T. Zwickel and J.C. Minx (eds.)].Cambridge University Press, Cambridge, United Kingdom and New York, NY, USA, pp. 811-922. 
International Journal of Agriculture and Environmental Research

ISSN: 2455-6939

Volume: 07, Issue: 03 "May-June 2021"

○ Chum, H., A. Faaij, J. Moreira, G. Berndes, P. Dhamija, H. Dong, B. Gabrielle, A. Goss Eng, W. Lucht, M. Mapako, O. Masera Cerutti, T. McIntyre, T. Minowa, and K. Pingoud, 2011: Bioenergy. In: IPCC Special Report on Renewable Energy Sources and Climate Change Mitigation, [Edenhofer, O., R. Pichs-Madruga, Y. Sokona, K. Seyboth, P. Matschoss, S. Kadner, T. Zwickel, P. Eickemeier, G. Hansen, S. Schlömer, C. von Stechow (eds.)]. Cambridge University Press, Cambridge, United Kingdom and New York, NY, USA, United Kingdom and New York, NY, USA, pp. 209-332.

- IPCC, 2018: Global Warming of $1.5^{\circ} \mathrm{C}$ An IPCC special report on the impacts of global warming of $1.5^{\circ} \mathrm{C}$ above pre-industrial levels and related global greenhouse gas emission pathways, in the context of strengthening the global response to the threat of climate change, [V. Masson-Delmotte, P. Zhai, H.-O. Pörtner, D. Roberts, J. Skea, P.R. Shukla, A. Pirani, W. Moufouma-Okia, C. Péan, R. Pidcock, S. Connors, J.B.R. Matthews, Y. Chen, X. Zhou, M.I. Gomis, E. Lonnoy, T. Maycock, M. Tignor, and T. Waterfield (eds.)]. World Meteorological Organization, Geneva, Switzerland, 1552 pp.

- Cecilia Tacoli et al., "Urban poverty, food security and climate change", Working Paper 37. International Institute for Environment and Development, London, 2013. http://pubs.iied.org/10623IIED.html

- Alexander K. A. et al., "Climate change is likely to worsen the public health threat of diarrheal disease in Botswana", INT. J. ENVIRON. RES. PUBLIC HEALTH,10(2013): 1202, http://www.ncbi.nlm.nih.gov/pubmed/23531489

- Moors E. et al., "Climate change and waterborne diarrhoea in northern India: impacts and adaptation strategies", SCI TOTAL ENVIRON, 468-469(2013): S139S151, http://www.ncbi.nlm.nih.gov/pubmed/23972324

- Nira Ramachandran, Persisting Undernutrition in India: Causes, Consequences and Possible Solutions (New Delhi: Springer, 2014)

- V. Ramana Dhara, Paul J. Schramm and George Luber, "Climate change \& infectious diseases in India: Implications for health care providers", INDIAN JOURNAL OF MEDICAL RESEARCH, 138(2013):

847, http://www.ncbi.nlm.nih.gov/pmc/articles/PMC3978971/ 